\title{
Características e Reactividade dos Compostos Orgânicos
}

\section{Resumo}

Depois de alguns anos como co-responsável das aulas teóricas da disciplina de Química Orgânica I, do tronco comum das Licenciaturas em Química, Química Tecnológica e Ensino da Física e da Química (variante Química) do DQB-FCUL, pude constatar que muitos alunos, já nos anos terminais dos respectivos cursos, cometem erros na escrita de estruturas de compostos orgânicos e de mecanismos reaccionais que não são perdoáveis a qualquer titular de uma licenciatura em Química. Através de uma abordagem simples, pretende-se neste trabalho evidenciar os conhecimentos que convém reter para quem quer continuar a trabalhar em Química. Espera-se também que as "dicas" consideradas essenciais para alicerçar de forma sólida a construção do "edifício da Química Orgânica" possam vir a ser úteis.

\section{Introdução}

É do conhecimento geral que os elementos mais usuais que aparecem nos compostos orgânicos são o carbono, hidrogénio, oxigénio, azoto, halogéneos (flúor, cloro, bromo, iodo), fósforo e enxofre. 0 tipo de ligação química característico destes compostos é a ligação covalente, caracterizada pela partilha de um par de electrões entre átomos adjacentes. A ocorrência de diferentes tipos de ligações químicas, em geral, pode ser explicada com base num conceito excepcionalmente importante e que é a electronegatividade associada aos átomos dos elementos. A electronegatividade de um átomo é tanto maior quanto maior for a sua capacidade de "puxar" electrões para si. Repare-se que todos os elementos acima referidos apresentam electronegatividades $(E)$ relativamente próximas, compreendidas entre 2,19 para o fósforo e 3,98 para o flúor (segundo os dados da Tabela Periódica dos Elementos, Porto Editora, 2000). Com base neste conceito, esperar-se-á que a nuvem electrónica de uma ligação carbono - hidrogénio $(E=2,55$ para $E=$ 2,20 , respectivamente) não esteja "puxada" em particular para nenhum dos átomos, mas o mesmo já não se poderá afirmar relativamente a uma ligação carbono - cloro $(E=2,55$ para $E=3,16$, respectivamente). Com efeito, a diferença de electronegatividades destes dois últimos átomos justifica a deslocalização da nuvem electrónica para o lado do cloro, o que faz com que essa ligação covalente esteja altamente "polarizada" Quando a diferença de electronegatividades entre dois átomos é superior a 2, a espécie química já apresenta carácter iónico, ou seja, em vez da partilha de um par de electrões, o elemento mais electronegativo tem tendência a "roubar" o electrão ao elemento de menor electronegatividade e a ligação química passa a ser iónica.

Os electrōes de cada átomo que estabelecem a ligação química são os electrões de valência, assim chamados por serem os que têm a capacidade de estabelecer ligações. Na Tabela 1 está indicado o número de electrōes de valência para cada um dos elementos acima mencionados, bem como a localização desses elementos em termos dos grupos e períodos que ocupam na Tabela Periódica.

A primeira regra de ouro a reter para interiorizar a química dos elementos per- tencentes ao $2 .^{\circ}$ período - excepção feita ao lítio e ao berilio - é ter em conta a chamada regra do octeto. Esta regra baseia-se no facto de que os elementos deste período, ao estabelecerem ligações químicas, não podem estar rodeados por mais do que 8 electrões, ou seja, o número máximo de ligações químicas que podem estabelecer é de 4 (podem, obviamente, apresentar menos). Por outro lado, deve ter-se também em conta que o cumprimento de tal condição para os átomos do $2 . .^{\circ}$ período, constituintes de uma dada espécie química, é factor adicional de estabilidade.

$\mathrm{Na}$ figura $1 \mathrm{~A}$ apresentam-se as estruturas de Lewis do metano, amoníaco, água e ácido fluorídrico, onde é possivel observar que todos os átomos verificam a regra do octeto - excepção feita ao hidrogénio, que não pode estar rodeado por mais do que 2 electrões.

Parece lógico que se considere que quando dois átomos estabelecem uma ligação covalente, é como se cada um deles possuísse 1 electrão; assim, pode verificar-se que, em todas as estruturas da figura 1A, o hidrogénio "tem" sempre 1 electrão, enquanto que o carbono tem 